\title{
Effect of credit guarantee policy on survival and performance of SMEs in Republic of Korea
}

\author{
Jae Won Kang · Almas Heshmati • \\ Gyoung-Gyu Choi
}

Published online: 26 September 2008

(C) Springer Science+Business Media, LLC. 2008

\section{Erratum to: Small Bus Econ \\ DOI 10.1007/s11187-007-9049-y}

The following author should be added to the list of co-authors:
Gyoung-Gyu Choi

Department of Management, International Programs and Education, Dongguk University, Seoul, Korea e-mail: gchoi@dongguk.edu

The online version of the original article can be found under doi:10.1007/s11187-007-9049-y.

J. W. Kang ( $\square)$

Technology Strategy and Planning Division, Korea Institute of Industrial Technology Evaluation \& Planning, 13F KOTECH Bldg. 701-7, Yeoksam-Dong,

Gangnam-Gu, Seoul 135-080, Republic of Korea

e-mail: pang77@snu.ac.kr; jkang@itep.re.kr

\section{A. Heshmati}

Economics \& Finance, University of Kurdistan Hawler, Hawler, Federal Region of Kurdistan, Iraq e-mail: heshmati@snu.ac.kr; almas.heshmati@ukh.ac

\section{G.-G. Choi}

Department of Management, International Programs and Education, Dongguk University, Seoul, Korea e-mail: gchoi@dongguk.edu 